\title{
Intelligence Decision Support Systems in E-commerce
}

\author{
Petr Suchánek, Roman Šperka, Radim Dolák and Martin Miškus \\ Silesian University in Opava, School of Business Administration in Karviná \\ Czech Republic
}

\section{Introduction}

The present state of world economy urges managers to look for new methods which can help to start the economic growth. To achieve this goal, managers use standard as well as new procedures and tools. Development of information society and so-called new economy has created a whole new business environment that is more extensive and rapidly changing. Become a standard the use of modern information and communication technologies (ICT), which enable faster and cheaper communication and an increase in the number of business activities. Today in the world's economy, a major role plays electronic business (e-business). Basic support for the e-business transactions are so-called e-commerce systems. E-commerce systems became standard interface between sellers (or suppliers and manufactures) and customers. E-commerce systems can be considered for systems with large geographical distribution. This follows from their nature, when they are based on the Internet. Statistics show an increasing interest in cross-border online shopping. This is also dependent on the efforts of manufacturers and retailers to establish themselves on foreign markets. Ecommerce systems allow them to do it quickly and at relatively low financial cost.

One of basic features of efficient e-commerce is correct definition and description of all internal and external processes. All the management activities and decision making has to be targeted to customers' needs and requirements. The optimal and most exact way how to obtain and find optimal solution of e-commerce system and its procedural structure is modelling and simulation. Organizations developing e-business and e-commerce solutions consider business modelling as a central part of their projects. The latest theoretical and practical experiences are testaments to how great strategic advantage for organizations doing business is creation and use of new e-business and e-commerce models. The importance and necessity of the creation and use of new models is described as the most recent publications, for example in (Laudon \& Traver, 2009) or (Laudon \& Traver, 2010) as well as in older, for example (Barnes \& Hunt, 2000). Next to the business model, a big attention must be paid to models of e-commerce systems from a technical point of view. (Rajput, 2000)

Expanded scope, creation and use of new models create the need for increased demands on decision-making. Social and business environment is changing very rapidly and this has an impact on managerial approaches. ICT became basic decision-making support. Technological bases of e-commerce systems are ERP and CRM systems, which constitute the core of enterprise informatics. Now almost all of them contain decision-making support 
modules and tools, which fall into the decision support system (DSS) or business intelligence (BI) category. In this context it is appropriate to ask, what is the difference between DSS and BI, how can these systems be used in e-commerce, which of these systems is more appropriate for decision support and what are the conditions that these systems could be classified as so-called intelligent decision support systems.

On the basis of these facts main goal of this chapter is to present new approaches to the creation of e-commerce systems models and new approaches to managing e-commerce systems using modern software tools for decision support.

\section{E-commerce system}

E-commerce systems are fundamental aids of online shopping. According to (Velmurugan \& Narayanasamy, 2008) e-commerce is defined as an attempt to increase transactional efficiency and effectiveness in all aspects of the design, production, marketing and sales of products or services for existing and developing marketplaces through the utilization of current and emerging electronic technologies. In the globalization era, understanding the adoption of information communication technology, including e-commerce by developing countries is becoming important to improve its adoption success. This, in turn, enables developed countries to trade with developing countries more efficiently.

Generally and simply, e-commerce system can be defined as a web server linked by company's information system. Detailed definition of e-commerce system appears from definition of information system whose basic components are information and communication technologies and users. Information systems are developed mainly for management support. Managers are in a way, a special group of users. Information system for them is on the one hand, a tool to support management activities, on the other hand, the source of current information describing the current state of managed objects. It is a principle of feedback, which is one of the fundamental principles of management.

Some authors (in some publications) consider as an e-commerce system only web server that contains all the necessary functionality (for example (Garcia et al., 2002)). Main model of ecommerce system based on process-oriented approach is shown for example in (Rajput, 2000). This model can be extended and then we can define main components of e-commerce systems which are (Fig. 1):

- customers;

- internet;

- $\quad$ web server (web interface);

- CRM (Customer Relationship Management);

- $\quad$ ERP (Enterprise Resource Planning);

- $\quad$ LAN (Local Network Area);

- payment system;

- delivery of goods;

- after-delivery (after-sales) services;

- information systems of cooperating suppliers and customers.

E-commerce systems are developed to support business activities. Customers (buyers) have their own requirements and corporate managers have to find all the ways, methods and resources to meet their needs and requirements. Great emphasis must be placed on all management control systems and systems to support the decision-making processes. The 
deployment of e-commerce could be seen mainly in the CRM (Customer Relationship Management), SCM (Supply Chain Management), FRM (Financial Resource Management), HRM (Human Resource Management), MRP (Manufacturing Resource Planning) and CPM (Composite Product Mapping).

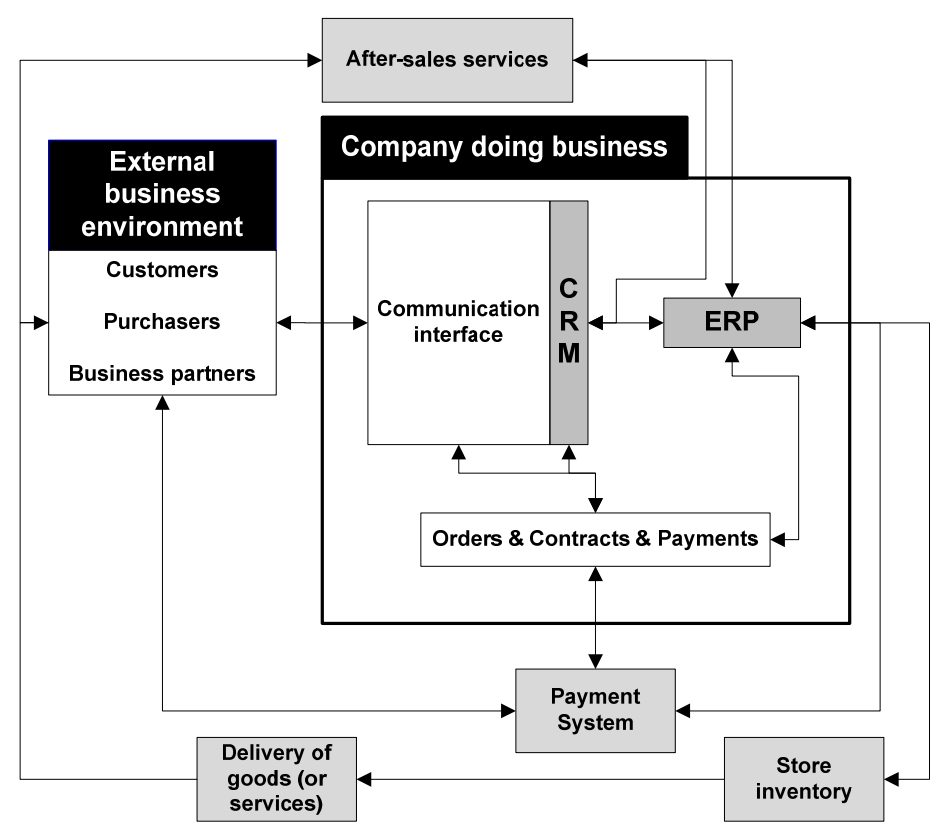

Fig. 1. E-commerce system

When implementing e-commerce system it is important to link new system with company's information system. All changes in e-commerce system will be immediately performed into the information system to ensure the data consistency. Enterprise Resource Planning (ERP) is suitable for global operations as it encompasses all the domestic jargons, currency conversions, diverse accounting standards, and multilingual facilities. ERP software attempts to integrate business processes across departments onto a single enterprise-wide information system. The major benefits of ERP are improved coordination across functional departments and increased efficiencies of doing business. The goal of CRM is to collect information gained by doing business in a central repository, analyze it, and make it available to all departments. In many cases, CRM are integrated into ERP, but it is not the rule. CRM and ERP benefits can be measured and quantified. With usage of ERP, company can gain following benefits:

- improved alignment of strategies and operations;

- improved productivity and insight;

- reduced costs through increased flexibility;

- $\quad$ supported changing industry requirements;

- reduced risk;

- improved financial management and corporate governance;

- $\quad$ optimized IT spending; 
- $\quad$ gained higher ROI (Return on Investment) faster;

- retained top performers;

- provided immediate access to enterprise information.

A major benefit of CRM can be the development of better relations with the existing and new customers, which can lead to:

- increased sales through better timing due to anticipating needs based on historic trends;

- identifying needs more effectively by understanding specific customer requirements;

- cross-selling of other products by highlighting and suggesting alternatives or enhancements;

- $\quad$ identifying which of your customers are profitable and which are not.

The condition of an entry to global markets through e-commerce deployment is an adjustment of the information system to global information and business system management standards. Management standards are defined for three basic sectors, which are customer relationship management, supply chain management and operating management. These sectors can be further refined into information system management, business processes management, management of logistics and production logistics, management of human resources, legal rules in relation to international law etc. (Vymětal \& Suchánek, 2009)

Payment systems are often one of the problem areas of e-commerce. It can be seen especially in the context of cross-border online shopping. There are numerous different payments systems available for online merchants. These include the traditional credit, debit and charge card but also new technologies such as digital-wallets, e-cash, mobile payment, echecks, cash on delivery. To support the cross-border online shopping development, it is necessary to provide the customers safe payment environment and to give support to the international bank clearing. It is one of the tasks of e-commerce system to ensure the correctness of financial flows e.g. from the sales when converting and storing the business results to the company's account information system. Dispatch is supported and controlled by SCM. SCM is the oversight of materials, information, and finances as they move in a process from supplier to manufacturer to wholesaler to retailer to consumer. Supply chain management involves coordinating and integrating these flows both within and among companies. Supply-chain management, at least in the largest multi-national corporations, is a global endeavor (Murillo, 2001). More about efficient SCM is discussed in (Šperka, 2010). Like every area of business in these days, e-commerce is surrounded by a maze of red tape, rules and regulations. In fact, selling online tends to be worse because of the international dimension. On the one hand, legislature can help to online shopping and cross-border online shopping, on the other hand it can scant e-commerce development (Suchánek, 2010a). Following part of the text is about requirements management. It will be explained why it's so important for companies to meet customers' requirements when developing an ecommerce system.

\section{Customer requirements and management needs}

When starting to develop an e-commerce system it is important to think about future functions of the system from the customer's point of view. Development process of the most recent projects initiates with requirements analysis. In terms of e-commerce, customer requirements can be separated up two groups. The first group of customer requirements results from exploitation of IS/IT as the main technological support of e-business and e- 
commerce environment. In 2003, ANEC Policy Statement on Design for All called upon the standard-makers to take the following generic consumer requirements into account when designing, selecting, commissioning, modifying and standardizing ICT systems. Requirements for IS/IT were summarized as accessibility/design for all, adaptability, child safety issues, comprehensible standards, consistent user interface, cost transparency, easily adaptable access and content control, ease of use, environmental issues, error tolerance and system stability, exportability, functionality of solution, health and safety issues, information supply for first-time user set-up procedure, interoperability and compatibility, multi-cultural and multi-lingual aspects, provision of system status information, privacy and security of information, quality of service, system reliability and durability, rating and grading systems, reliability of information, terminology. (ANEC, 2005)

The second group of customer requirements is closely associated with business transactions (Suchánek, 2010a). Customers want to find what they want easily and in short time, to get sufficient number of information, to place an order easily, payment system to be secured and failsafe, to get goods in quality of service and in short time, goods to be guaranteed by sellers (producers) and to get benefits in dependence on a number of purchases. To be reliable in an uncertain and changing environment companies must be able to respond to the changes quickly. To obtain it, management needs actual information. The most important condition of customer satisfaction is feedback. Suppliers and producers have to monitor market environment and all have to be targeted to the customers. All customer requirements have to be monitored for ever and company information system with the all company' processes have to be formed to ensure quality and rapid processing of the all customer feedback information, needs and requirements. Feedback information can be getting by the communication channels which are usually integrated in CRM (Customer Relationship Management). Feedback is the most important condition of getting information. If managers want to satisfy all customer requirements, they should:

- get precision information;

- $\quad$ get information in time;

- get information in required form;

- $\quad$ get information in visual form;

- $\quad$ know information they want to.

Managers need besides information:

- to develop the ability to apply information technology in complex and sustained situations and to understand the consequences of doing so;

- to learn the foundations on which information technology and applications are built;

- $\quad$ and current or contemporary skills.

\section{Decision-making processes in e-commerce system environment}

When the company, implementing e-commerce system wants to use full potential of new solution it is necessary to decide according to the relevant information. E-commerce systems produce amount of raw data. Why not to use these data to improve the decision-making? Decision Support System (DSS) is an umbrella term used to describe any computer application that enhances the user's ability to make decisions. More specifically, the term is usually used to describe a computer based system designed to help decision makers use data, knowledge and communications technology to identify problems and make decisions to solve those problems. DSS systems can be separated into seven broad categories namely 
Communications Driven DSS, Data Driven DSS, Document Driven DSS, Knowledge Driven DSS, Model Driven DSS, Spreadsheet based DSS and Web-based DSS. Communications Driven DSS is a type of DSS that enhances decision-making by enabling communication and sharing of information between groups of people. Data Driven DSS are a form of support system that focuses on the provision of internal (and sometimes external) data to aid decision making. Document Driven DSS are support systems designed to convert documents into valuable business data. Knowledge Driven DSS are systems designed to recommend actions to users. Model Driven DSS support systems incorporate the ability to manipulate data to generate statistical and financial reports, as well as simulation models, to aid decision-makers. Spreadsheet based DSS offer decision-makers easy to understand representations of large amounts of data. Web-based DSS system is operated through the interface of a web browser, even if the data used for decision support remains confined to a legacy system such as a data warehouse. (Velmurugan \& Narayanasamy, 2008)

Decision making processes need combination of skills, creativity, recognition of the problems, and lucidity of judgment, determination, and effective implementation in operational plan. Generally, decision making process has five stages: (Harrison, 1998)

- problem determination (definition of objectives);

- collection of information (identification of alternatives);

- choosing of optimal decision;

- implementation of a decision;

- evaluation of decision.

To adopt a right decision, managers have to get correct information in right time. In connection with e-commerce source system of data set is extended. With a view to minimization of failure during the domestic and especially cross-border online selling, it is necessary to allow for many factors. Besides typically economic indicators, source information of management systems have to be for example legislature, culture, conventions etc. (Fig. 2)

Decision making processes are also proceed on the side of customers. The customers' decision-making process is the process they go through when they decide to purchase something. (Olsen, 2003) Research suggests that customers go through a five-stage decisionmaking process in any purchase:

- need recognition and problem awareness;

- information search;

- evaluation of alternatives;

- purchase decision;

- post-purchase evaluation.

Managers' decisions should lead to make the customers' decision-making process easier. All decision making processes have to be targeted to the customers and their needs and requirements. Customers' needs and requirements are usually different in a number of countries. This fact is always a cause of unsuccessfully cross-border online selling transactions. Only the way leading to reduce the number of unsuccessfully cross-border online selling transactions is an optimal management system making use of all necessary source information. To obtain an efficient decision-making, there are used mathematical models of allocation processes (Bucki, 2008). More about mathematical model of ecommerce simulation example is written at the end of this chapter. Supranational character of e-commerce systems evokes the need to process an extensive set of information and urges 
the managers to look for the new methods leading to maintenance and improvement of position in domestic and especially foreign markets. This is possible only with the aid of modern information technologies. Current trend is oriented to the development and usage of systems with business intelligence tools. (Suchánek et al., 2010b)

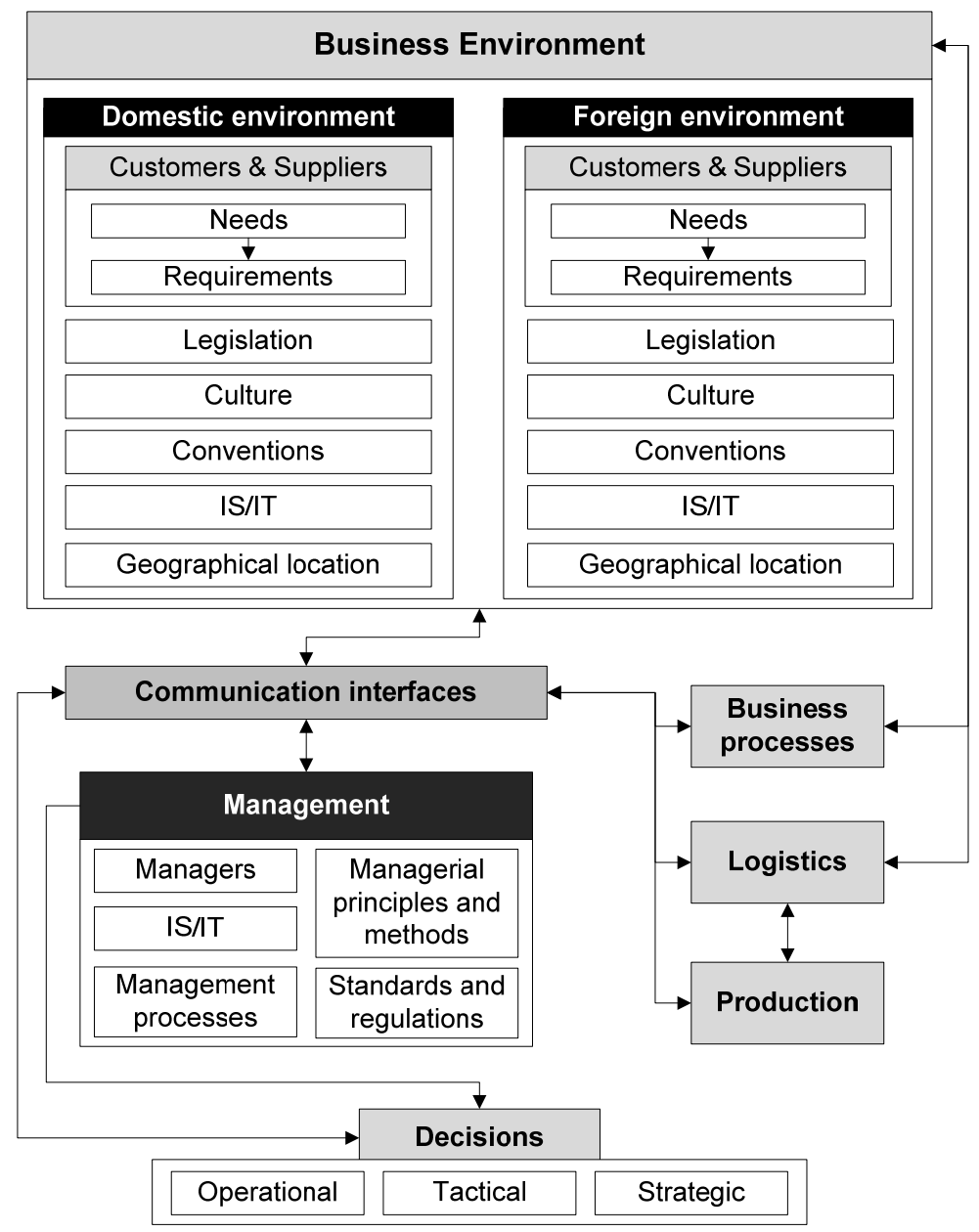

Fig. 2. Management system and its source information areas

\section{E-commerce systems modelling to assess the added value}

Modelling and system design techniques are currently widely required. This is caused by information technologies support needed to achieve and sustain necessary business flexibility imposed by market fluctuations. There are two substantial ways to use the model. During the system design, the model serves as a conceptual description of the future system. After the new system is put into operation, the management can use it also for decision 
support. Typical management control loop incorporates the measurement of the controlled system outputs ("what has happened" - facts) which are evaluated and compared with the company objectives (targets). The controller - manager then takes corrective action ("what should or must be done") in order to reach the specified targets. In case of decision support by simulation the outputs of the controlled subsystem and the data concerning company environment have to be included in the model structure. The results of simulation are presented to decision maker - manager for evaluating possible decision alternatives. While conceptual modelling forms the base of new system design, the simulation modelling can be seen as operations support. This is why both ways of modelling are important for achieving flexibility of data processing in particular, the company management effectiveness in general.

E-commerce systems to work properly should support and cover all company's core processes. Correct processes identifying, mapping and implementing into e-commerce system is the main condition of successful business. E-commerce dramatically and strategically changes traditional business models. Companies are now pursuing more intensive and interactive relationships with their business partners: suppliers and customers. Competitive conditions and pressures on global market are forcing companies to search for strategies of streamlining the entire value chain. To compete effectively, companies must structurally transform its internal and external processes. These goals could be reached by simultaneous renovation of business processes and implementation of electronic business solutions. Business Process Reengineering (BPR) is an organizational method demanding radical redesign of business processes in order to achieve more efficiency, better quality and more competitive production. BPR has become one of the most popular topics in organisational management creating new ways of doing business. Many leading organisations have conducted BPR in order to improve productivity and gain competitive advantage. However, regardless of the number of companies involved in reengineering, the rate of re-engineering projects success is less than $50 \%$. Some of the frequently mentioned problems related to BPR include the inability to accurately predict the outcome of a radical change, difficulty in capturing existing processes in a structured way, shortage of creativity in process redesign, the level of costs incurred by implementing the new process, or inability to recognize the dynamic nature of the processes. An e-commerce model generally means the adoption of company's current business model to the Internet economy. Main purpose of developing and analysing business models is to find revenue and value generators inside reversible value chain or business model's value network. BPR in 90-s has been focused on internal benefits such as a cost reduction, downsizing of company and operational efficiency which is rather tactical then strategic focus. Nowadays, e-business renovation strategies put their focus on the processes between business partners and the applications supporting these processes. These strategies are designed to address different types of processes with the emphasis on different aspects: customer relationship management (CRM), supply chain management (SCM), selling-chain management and enterprise resource planning (ERP).

It is well known that e-commerce might bring several advantages to the company. However, existing practical business applications have not always been able to deliver the benefits they promise in the theory. Prior to adopting e-business, companies need to assess the costs needed for setting up and maintaining the necessary infrastructure and applications and compare it with the expected benefits. Although the evaluation of alternative solutions 
might be difficult, it is essential in order to reduce some of the risks associated with BPR projects.

Before implementing the e-commerce model we should know if the designed model works properly. For this verification process is often used the simulation. Simulation has an important role in modelling and analysing the activities in introducing BPR since it enables quantitative estimations of influence of the redesigned process on system performances. Simulation of business processes represents one of the most widely used applications of operational research as it allows understanding the essence of business systems, identifying opportunities for change, and evaluating the impact of proposed changes on key performance indicators. The design of business simulation models that will incorporate the costs and effects of e-commerce implementation and will allow for experimentation and analysis of alternative investments is proposed as a suitable tool for BPR projects. Some of the benefits can be directly evaluated and predicted, but the others are difficult to measure (intangible benefits).

\subsection{Process oriented approach}

Often used approaches to model the e-commerce systems are process and business oriented systems. Process oriented model will be used to describe the basic structure and data flow. Process modelling is one of the most cost-effective and rewarding ideas to come along in years. Many different techniques can be used for modelling business processes in order to give an understanding of possible scenarios for improvement. Flowcharting, IDEF0, IDEF3, Petri Nets, System Dynamics, Knowledge-based Techniques, Activity Based Costing and Discrete-Event Simulation are only some examples of business process modelling techniques widely used. There are also many software tools on the market using these modelling techniques. In terms of methods, we can use three ways of modelling. Ecommerce systems can be modeled using process-oriented, value-oriented and/or multiagents-oriented approaches.

The goal for process-oriented modelling is a specification of activities and their structure. Each activity can be looked upon as a process and decomposed into further ones until the set of single activities is reached. The activities do not come into being or exist independently from the environment. They are instigated by defined external or internal impulses or reasons. The basic elements of a process model include usually (Řepa, 2006):

- process;

- activity;

- initiative or instigation;

- relations among processes and activities.

Process oriented approach can be used for many purposes. As an example we can specify the model describing the activities taking place during the execution of transactions in the on-line shopping. A diagram of existing process could be seen on Fig. 3.

In many cases customers find and select a product in web-stores and then buy it later in traditional (physical) stores. The technique should be capable of representing one of more of the following modelling perspectives: functional (represents what activities are being performed), behavioural (represents when and how activities are performed), organizational (represents where and by whom activities are performed) and informational (represents the informational entities - data). (Bosilj-Vukšic et al., 2010) 


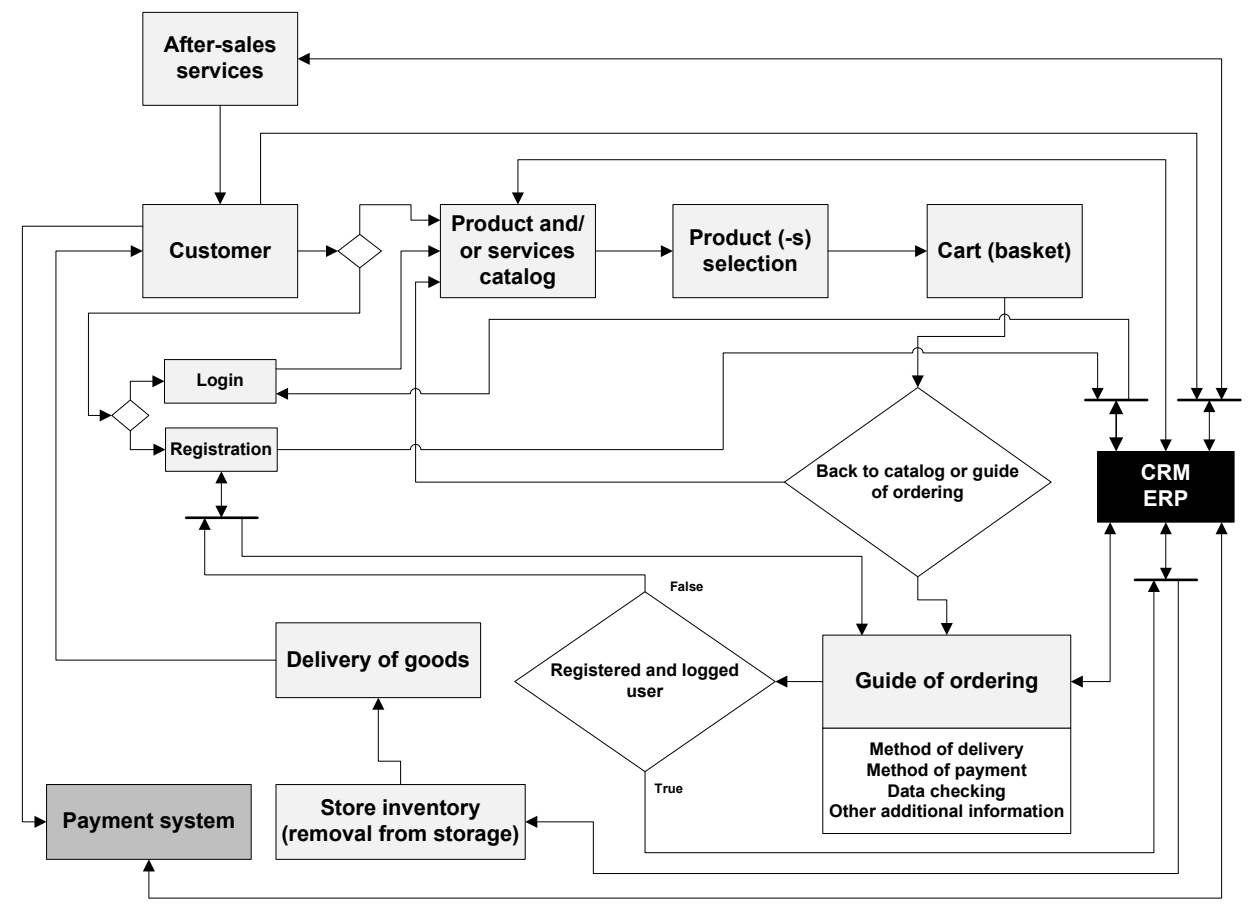

Fig. 3. Process model of e-commerce system

\subsection{Value-chain oriented approach}

Business oriented model works with value chains of business processes. It is used to define the methods and possibilities of e-commerce system. A Value Chain perspective, developed and introduced by Michael Porter (Porter, 1980) can be arranged as a series of input-output business processes with resource flows between them. (Dunn et. al., 2005), (Hruby, 2006). Value chain models deal with the participants of the value flow (customer, enterprise etc.); define the objects of value flow (like goods, services, cash) and types of economic events accomplishing the actual value flow itself. The basic difference to traditional business process models explains how processes happen by means of general process description concepts such as the activity, entity, process state, is that value chain models explain why processes happen in terms of the added value to the participants' entrepreneurial goals.

\subsection{Multi-agents oriented approach}

Another attitude to this activity brings the advantages of the model based on multi-agents oriented approach to model the e-commerce system and to validate it with simulation. (Vymětal, 2009) gives perfect example for using multi-agents simulation in business processes of a corporation. (Šperka, 2010) explains the advantages of multi-agents simulation methods for the increasing of the competitiveness of the enterprises. A multiagent system is a system composed of multiple interacting intelligent agents. Multi-agent systems can be used to solve problems which are difficult or impossible for an individual 
agent or monolithic system to solve. Examples of problems which are appropriate to multiagent systems research include online trading, (Rogers, 2007) disaster response, (Schurr, 2005) and modelling social structures. (Ron \& Naveh, 2004) The agents in a multi-agent system have several important characteristics: (Wooldridge, 2004)

- $\quad$ autonomy - the agents are at least partially autonomous;

- local views - no agent has a full global view of the system, or the system is too complex for an agent to make practical use of such knowledge;

- decentralization - there is no designated controlling agent (or the system is effectively reduced to a monolithic system). (Panait \& Luke, 2005)

Typically multi-agent systems research refers to software agents. However, the agents in a multi-agent system could equally well be robots, (Kaminka, 2004) humans or human teams. A multi-agent system may contain combined human-agent teams. Multi-agent systems can manifest self-organization and complex behaviors even when the individual strategies of all their agents are simple. Model based on multi-agents-oriented approach can be used to define the methods and possibilities of e-commerce systems simulation.

As above, in the area of e-commerce, multi-agent system (MAS) consists of various number of software components, called agents. An agent is an entity that is designed to undertake autonomous action on behalf of a user in pursuit of his desired goal. This implies that agents are intelligent and autonomous objects that are capable of behaving like a human being. Therefore agent technology is a suitable means for expanding business activities and saving cost. Agents possess some form of basic intelligence to allow decision-making or have a structured response to a given set of circumstances. These behaviour patterns are acquired from or given to the agent by the user, this enables the agent to be capable of flexible actions. Allowing it to exhibit good oriented and opportunistic behaviour to meet it's objective. Agents exist in an environment and can also respond to changes therein. Complex tasks can be broken down into smaller components that can each be the responsibility of an agent. They concentrate on their individual components, find optimal solution and combine their efforts by inter-agent communication. (Folorunso et al., 2006)

\section{Parameters for describing models}

Models can be described by a number of parameters which are often called key indicators. There are a number of indicators that can be measured and calculated and by which we can make a description of current e-commerce system performance. If we consider the sales system in the form of an internet shop (e-shop), fundamental question is what are the most important indicators and key numbers that can be used to measure the success or failure of internet-based sales, rather e-commerce system, and how can they be measured? Measurement is a very important thing, because in general, what can't be measured, can't be improved. In this context, objective will be the systemization of measurable key indicators, which are input values of DSS and BI.

Within e-commerce systems, measurements can be divided into the following types:

- $\quad$ performance measurement - measurement of technical parameters (for example web page load time, speed of processing user commands, speed reporting, etc.);

- usability testing - usability testing is done in laboratory conditions (for experienced users are set various tasks); 
- measurement of the success - measurement of the success should answer the question how e-commerce system helps to meet company objectives. Outcomes of this measurement are used primarily to optimize and control.

Source data can be divided into next groups:

- operational characteristics - on the web interface there are, for example, number of displayed web pages, number of website visitors, in connection with the information system there can be, for example, number of successfully completed transactions, number of failed transactions (may be associated with system disturbances), etc.;

- customer data - data relate primarily to demographic characteristics of visitors and their preferences (city listed in the order, city listed in the query or demand, gender of customer, etc.);

- transactional data - data directly related to the sale of goods or services. These data are the basis for financial analysis. (average order value);

- data from other sources - other data relating to consumer behaviour in the website.

\subsection{Key indicators of websites success and performance}

One of the technologies used for the web indicators measurement is so called clickstream. (Sweiger et al., 2002) The result of clickstream analysis may be two groups of characteristics. Outputs belonging to the first group are data representing the operating characteristics (for example number of pages viewed, number of unique IP addresses, etc.), the second group consists of characteristics of a commercial nature (cross-selling analyses, abandonment of the shopping cart, number of the orders, etc.). Other outputs, which are the numbers of orders, inquiries, etc. are processed and analyzed in the context of CRM and ERP. In these systems some specific business cases and business activities are already processed. Generally, on the website, measurements can be realized with help of traffic volume measurement from panels, TCP/IP packet sniffing, direct server measurement, browser based measurement, server-based measurement or internet traffic measurement.

The first group of parameters includes the key indicators for the measurement of the ecommerce system success. In this case, the input data are the number of days (time period), site visits (unique visits), number of demands received from the web, number of orders received from the web, number of users who have made an order, and data from CRM and ERP (amount of orders - revenue, margin orders).

Based on these input data, there can be made the calculations, from which we can obtain sales (total orders), margin (after deduction of all costs), conversion ratio of demands, conversion ratio of orders, average value per order, average returns per customer, average number of order per customer, average margin of one order, average margin per customer, average returns per visit, average margin per demand, and average margin per visit. These indicators are used for the basic analysis and are very important for the management activities related to the sale, planning and finance.

Web interface is usually a part of a CRM system that is connected with the ERP. CRM and ERP are the information systems that are at the core of the enterprise informatics. The indicators from this group belongs to the area of IS/IT. The basic indicators for the proper operation of the information system are: system availability, average response time, breakdown intensity, breakdown rate, average download time, failure rate.

The integral part of the enterprise information system is created by its users at all levels of the corporate activities, and in particular, of the management. Each user carries out various 
activities, while each of them constitutes interference in the system. In this context, there are indicators that can be included in the administrative field, partly in the area of security and personnel. In this group of indicators, there can be included: number of correct user intervention, number of incorrect user intervention (for example, it may be related to poor secure system, inappropriate user interface, incompetence users), number of system administrator intervention (corrections system) and number of users involved in processing by one commercial transaction.

Another important area is the logistics. The logistics is a channel of the supply chain which adds the value of time and place utility. The basic indicators tracked in this area are: product availability, number of successfully delivered products, number of unsuccessfully delivered products (for example customer entered incorrect address or error occurred at the side of vendor or carrier), average length of warranty service, storage costs, cost to deliver goods, average delivery time of goods, number of cooperating suppliers offering the same goods.

The Internet has allowed the development of the new methods of marketing that provide very important information useful for the management support and the planning. In this area, the important key indicators are: number of unique customers, average visit frequency, number of repeat customers, margin per customer, number of first buyer, average sales per repeat customers, average order value per repeat customer, market share, percentage share of new vs. returning visitors, average conversion rate, average time spent on the website, average number of pages displayed per visit, percentage share of returns (one page visits), average number of clicks on adverts. One of the key methods of e-marketing is a campaign. For example, in the campaigns we can trace percentage share of visits according to the type of campaign and percentage share of conversion rate according to the type of campaign. These values are the basis for the determination of index of campaign quality.

The e-commerce systems are implemented with a goal to expanse the sales channels, and thus to increase the profits. In this context, the important general indicator is the return on investments (ROI). To calculate ROI in the web projects, we can use, inter alia, an online calculator on the website. In this case, the source data can include: number of days (time period), regular fixed cost (the cost of webhosting, salary, etc.), cost per customer acquisition, the current daily visit site, the current conversion ratio of orders, the percentage increase of conversion ratio due to investments, percentage increase of average order value due to investments, estimated average order value increase after, the current average margins, the percentage increase of average margins due to investment, and estimated average margin value increase after.

Using these data, we can calculate: number of visitors, number of orders, yields, margins, fixed costs, direct cost of acquiring visitors, profit, profit per days, and return on initial investments.

\subsection{Data in e-commerce systems}

E-commerce system produces a huge amount of data collection. Data has potentially great value. Data must be accepted, processed and appropriately presented. This is the main prerequisite for successful management. To adopt a right decision, managers have to get correct information in right time. In connection with e-commerce and especially online selling, source system of data set is extended. With a view to minimization of failure during the domestic and cross-border online selling, it is necessary to allow for many factors. Besides typically economic indicators, source information of management systems have to be for example legislation, culture, conventions etc. (see Fig. 2) 
Data can be processed by the using of ICT and then may be obtained from them valuable information for decision-making. We can find new customer segments, analyze trends or uncover new business opportunities. Business intelligence solutions are used for the purposes of advanced data analysis and search for hidden dependencies. Business intelligence aims to support better business decision-making and also can be helpful in process of retaining existing customers and acquiring new customers. In next part of this chapter will be mentioned more about BI.

\section{Business intelligence}

It's common knowledge that Decision Support Systems are a specific class of computerized information system that supports business and organizational decision-making activities. A properly designed DSS is an interactive software-based system intended to help decision makers compile useful information from raw data, documents, personal knowledge, and/or business models to identify and solve problems and make decisions. But what about socalled intelligence decision support system? What should this type of systems meet the requirements? From our perspective, an intelligent decision support system is a system containing BI tools. Business Intelligence is a term that refers to the sum total, or effect, of gathering and processing data, building rich and relevant information, and feeding it back into daily operations so that managers can make timely, effective decisions and better plans for the future. Generally business intelligence brings to managers a quite number of advantages. The advantages enjoyed by market leaders and made possible by business intelligence include the high responsiveness of the company to the needs of its customers, recognition of customer needs, ability to act on market changes, optimization of operations, cost-effectiveness, quality analysis as the basis for future projections, the best possible utilization of resources etc.

Business intelligence is oriented to the management needs and decision making support. Optimal setting of control processes is a prerequisite of the planned and expected aims. Business processes are the collections of activities designed to produce a specific output for a particular customer or market. It implies a strong emphasis on how the work is done within an organization, in contrast to a product's focus on what. To do right decisions, managers need information. Data that is relevant to a business decision may come from anywhere. The most important sources of data include: (Suchánek, 2010a)

- Master data - this is data collected (usually once and once only) to define the entities in an e-business system (customer file, product file, account codes, pricing codes, etc...). Scores of the time we can meet with term of Master Data Management (MDM). MDM comprises a set of processes and tools that consistently define and manage the nontransactional data entities of an organization (which may include reference data).

- Configuration data - as the term implies this is data defining the nature of the system itself. The system is configured to reflect the nature and needs of the business.

- Operations data (OLTP - Online Transaction Processing) - also known as activity. This data is generated by daily business activities such as sales orders, purchase orders, invoices, accounting entries, and so on. OLTP refers to a class of system that facilitates and manages transaction-oriented applications, typically for data entry and retrieval transaction processing.

Information systems (OLAP - Online Analytical Processing) - these are sophisticated applications collecting information from various internal and external sources to analyze data and distill meaningful information. OLAP software is used for the real-time analysis of 
data stored in a database. The OLAP server is normally a separate component that contains specialized algorithms and indexing tools to efficiently process data mining tasks with minimal impact on database performance.

Almost all requisite data for the decision making support in e-commerce comes from CRM and ERP systems. Business intelligence is closely related to data warehousing. Data has to be processed (data selection, data analysis, data clearing etc.) and sent in right time and in required form to the competent person usually acting in management system. (Fig. 4) Obtained data are basis for decision making support at all levels and kinds of management.

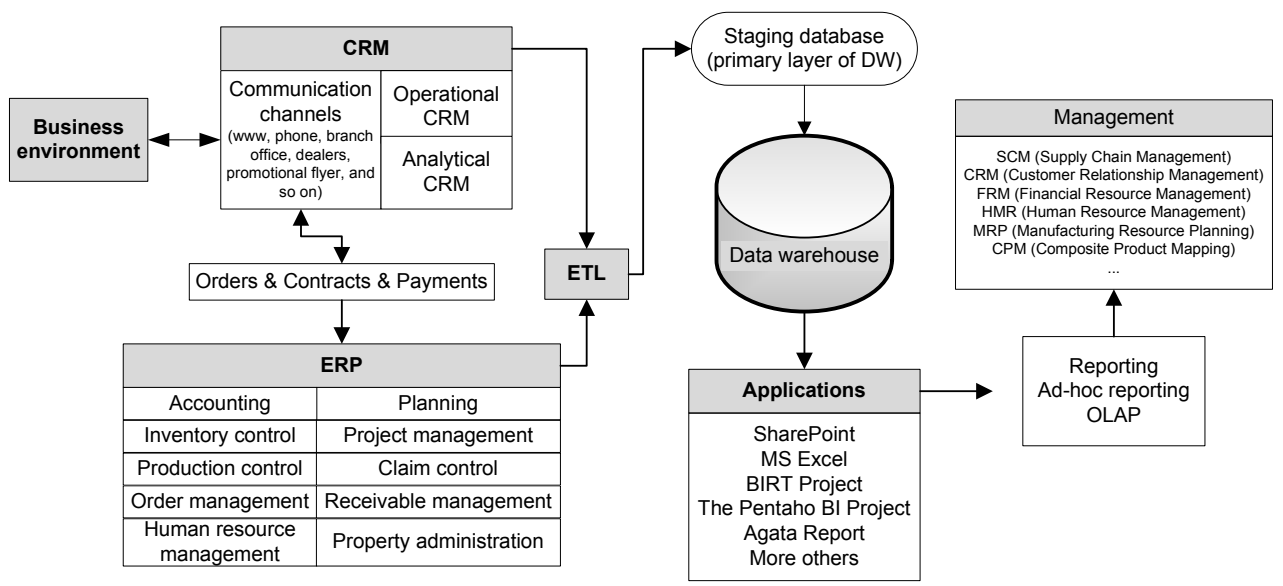

Fig. 4. Business intelligence system. Source: Suchánek, 2010a.

Data processing is supported by ETL (Extraction, Transformation and Loading). The ETL process is also very often referred to as Data Integration process and ETL tool as a Data Integration platform. The terms closely related to and managed by ETL processes are: data migration, data management, data cleansing, data synchronization and data consolidation. (ETL-Tools.Info, 2009)

The purpose of the Data Warehouse in the overall Data Warehousing Architecture is to integrate corporate data. Data warehousing evolved through 1990s to environments that typically featured batch-oriented "stocking" and "restocking" of the data warehouse, primarily for purposes of after-the-fact reporting and analysis. (Simon \& Shaffer, 2001) The amount of data in the data warehouse is massive. Data is stored at a very granular level of detail. For example, every sale that has ever occurred in the organization is recorded and related to dimensions of interest. This allows data to be sliced and diced, summed and grouped in unimaginable ways. Recent technological advancements in data warehousing have been contributing to the emergence of business intelligence useful for managerial decision making. (Taniar, 2009)

BI applications are for example SharePoint, MS Excel, BIRT Project, The Pentaho BI Project, Agata Report and many others (some of applications can be interconnected). These applications are fundamental interface between system and managers. With the aid of shown application users can choose and manipulate a wide variety of visual representations, including map-based data displays to review business intelligence reporting results geographically, multidimensional scatter plots to view data statistically, 
and bar charts, pie charts, line graphs, profile charts and more. At present, when the world economic conditions are not affable, companies look for all information which would help them to start economic growth. In this respect e-commerce companies have recently started to capture data on the social interaction between consumers in their websites, with the potential objective of understanding and leveraging social influence in customers' purchase decision making to improve customer relationship management and increase sales. (Young \& Srivastava, 2007)

Business intelligence systems are able to provide the managers quite a number of statistics dealing with customers and their environment. As important customer statistics can be considered, for example, matching sales revenues with site visitor activity, by week and month, in total and by product line, matching weekly and monthly sales with site visitor activity over time (trend analysis), in total and by product line, matching sales revenues with site visitor activity, by day and hour, in total and by product line (to measure the effectiveness of advertising campaigns), matching sales revenues with site visitor activity from main referrers, by week and month, in total and by product line. Where the referrer is a search engine, also matching the search query with sales revenues. These statistics respond the managers to questions:

- Who did buy?

- How much did they buy?

- When did they buy?

- What did they buy?

- From where customers arrived at the site?

- In which region customer are located?

- How they arrived at the site (e.g. by what search engine query)?

- From which page customer entered the site?

- What is their path through the site?

- From which page customer left the site?

- On a weekly and monthly basis and the trends, over time.

Advantages and benefits of business intelligence in the sphere of e-commerce can be summarized as:

- Business intelligence gives any firm the specific view of corporate data that is required for progress (quickly access sales, product and organizational data in any database).

- In sales and marketing, business intelligence offers new tools for understanding customers' needs and responding to market opportunities

- By providing financial planners with immediate access to real-time data, Business Intelligence builds new value into all financial operations including budgeting \& forecasting.

- Business intelligence supports decision-making with automatic alerts and automatically refreshed data.

- Business intelligence provides performance monitoring for accelerated action and decision making.

- Business intelligence makes companies possible to receive and process data from crossborder business activities (above all from cross-border online shopping).

- Business intelligence can bring to companies competitive advantage. 
Besides data from business intelligence systems, companies can use services of the consultation companies. There are many consultation companies providing information and doing analyses. Correct source information are necessary, but usually have to be paid for. There are many sources providing statistical data on the Internet, but these are usually not adequate. Managers can acquire correct information from the many sources. (Molnár, 2009) Following sources supply the attested information usable for manager's decision making in the global markets. Foreign stock market information can be found on (for example):

- $\quad$ http://www.bloomberg.com;

- http://www.dowjones.com;

- http://www.nyse.com;

- http://www.nasdaq.com;

- http://www.reuters.com;

- http://money.cnn.com;

- http://www.imrworld.org/;

- http://finance.yahoo.com/;

- http://www.marketwatch.com/;

- http://www.indiainfoline.com/.

Marketing information can be found on (for example):

- http://www.formacompany.ie;

- http://reports.mintel.com/;

- http://www.eiu.com;

- http://www.frost.com;

- $\quad$ http://www.adlittle.com;

- http://www.datamonitor.com;

- http://www.euromonitor.com/.

Law and legislative information can be found on (for example):

- $\quad$ http://www.iblc.com/home/;

- http://www.iblc.com/;

- http://www.ibls.com/;

- http://www.enterweb.org/law.htm;

- http://euro.ecom.cmu.edu/resources/elibrary/ecllinks.shtml.

Properly implemented BI tools into the DSS in conjunction with multi-agents-oriented approach enable the implementation of simulation methods. Simulation can be described as a technologically and logically the highest level of decision-making support. DSS allows simulation can fit neatly into the category of intelligent DSS.

The reasons for the introduction of simulation modelling into process modelling can be summarized as follows (Bosilj-Vukšic et al., 2010):

- $\quad$ simulation enables modelling of process dynamics;

- influence of random variables on process development can be investigated;

- anticipation of reengineering effects can be specified in a quantitative way;

- $\quad$ process visualization and animation are provided;

- $\quad$ simulation models facilitate communication between clients and an analyst.

In this context, in the following section, we will present an example of simulations that can be carried out within the e-commerce system. 


\section{Simulation of e-commerce systems}

Simulation is generally defined as a method to analyze the behavior of complex systems by monitoring the behavior of the model (currently in particular computer model). Simulation system can be described as intelligent decision support systems. Simulation system must take into account all the areas described in the preceding sections. Simulation system should allow to enter input parameters which are analyzed by the system. The resulting output parameters describe the state of the system under the conditions of entry.

\subsection{Control loop as the default model of simulation system}

A suitable way can be a system simulation based on the control loop (Fig. 5).

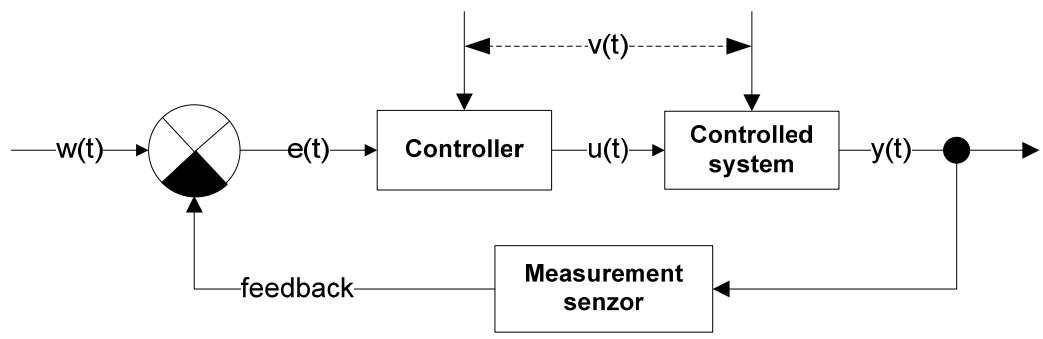

Fig. 5. Control loop

Key to figure: $w(t)$ - desired value; $e(t)$ - controller error $(w(t)$ - value of feedback); $u(t)$ manipulated variable; $\mathrm{y}(\mathrm{t})$ - process variable (output value); $\mathrm{v}(\mathrm{t})$ - disturbances

Diagram in Figure 5 can be used as a starting model for a generic model of e-commerce system (Fig. 6). A similar, much simpler model can be found for example in (Wolf, 2006).

Model in Figure 6 can be used to create realistic simulation models based on software support. Input variables (desired value) represent the input data of simulation. This data can be entered by the user manually or automatically generated for example by genetic algorithms when the user only sets the initial conditions (criteria).

\subsection{Integration of simulation into the management structure}

For a comprehensive description of the architecture and design of simulation system three layers can be used (Fig. 7). There is a layer of management control activities primarily focused on real activity. The default values used in the simulations as a comparative are contained in the plan. Real regulatory interventions are implemented after their verification in the simulation layer. In the layer of simulations we can perform simulations based on all types of models (process oriented, value-chain oriented, multi-agents). Assuming the correct model and mathematical description, this system may help managers to test some of the assumptions on which it can be effective decisions.

As we can see in Figure 7, simulation system should be integrated into the overall management system. Whereas, for the purposes of simulation software tools are used, integration of simulation into the management system is becoming increasingly easier. Economic system simulations are used increasingly. Reason is the advantages of simulation, which can be facts, that simulations are able to provide users with practical feedback when designing real world systems; simulations permit system designers to study a problem at several different levels of abstraction and/or simulators can be used as an effective means for teaching or demonstrating concepts to students. 


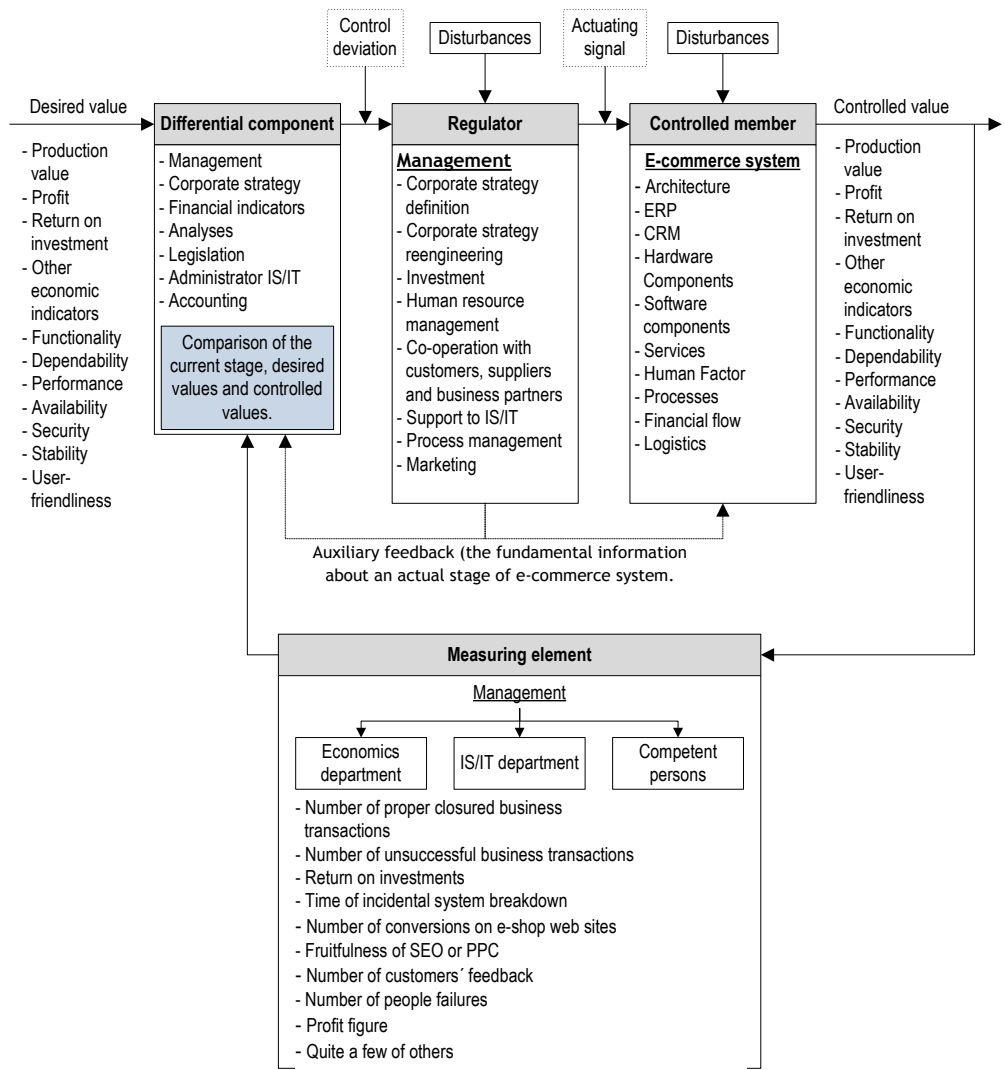

Fig. 6. Generic e-commerce model

\section{Conclusion}

E-commerce systems are fundamental aids of online shopping. These systems are focused on customer needs and requirements. E-commerce systems are large systems and produce a huge amount of data collection particularly data related to the behavior of customers. Data has potentially great value for management and decision making support. Data must be accepted, processed and appropriately presented using appropriate tools. Only modern software tools can provide data quickly and with the required quality. Modern software tools for processing large data collections are BI and DSS systems. Development of ecommerce systems places increasing emphasis on the need to create models of these systems. The modelling of e-commerce systems can be effectively done by use of a processoriented approach, value-oriented approach or approach based on multi-agents systems. The main difference between process modelling and value chain modelling is that process modelling specifies "How" a process is realized and implemented, while value chain modelling specifies "Why" the process occurs in terms of added value to the process participants. Multi-agents approach is primarily used to support simulation.

Simulations more often help the managers implement viable plans and adequate management activities. Simulation system can be described as intelligent decision support 
systems. Important is that the simulation system would be integrated into the management system as an automatic or semiautomatic system.

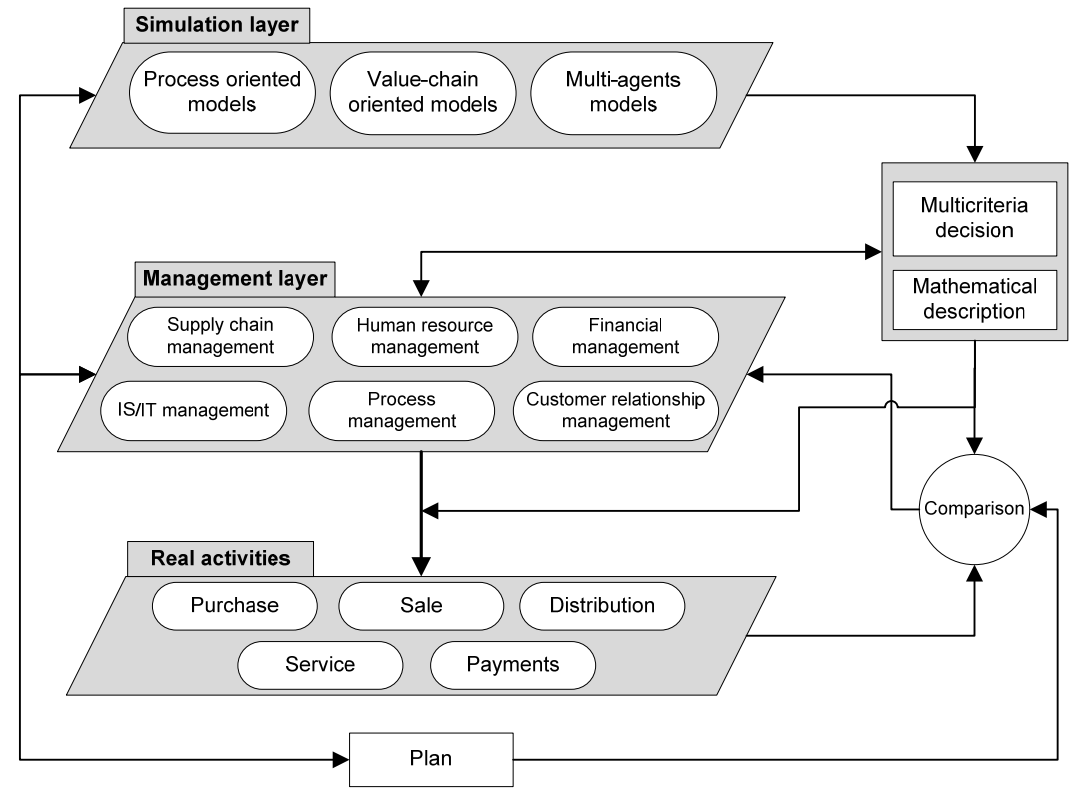

Fig. 7. The model links management layers, real activities and simulations

\section{Acknowledgment}

Chapter's content is based on the outputs of the project SGS/24/2010 - Use of BI and BPM to support effective management (project is carried out at The Silesian University in Opava, School of Business Administration in Karviná - Czech Republic).

\section{References}

Agrawal, P. (2006). E-Business Measurements and Analytics: (Measuralytics). iUniverse, Inc., 91 p., ISBN 978-0595398386, Bloomington, USA

ANEC. (2005). Consumer Requirements in Standardisation relating to the Information Society. 05.05.2009, Available from http://www.anec.org/attachments/it008-03rev1.pdf

Arai, T., Kragic, D. (1999). Variability of Wind and Wind Power, In: Wind Power, S.M. Muyeen, (Ed.), 289-321, Scyio, ISBN 978-953-7619-81-7, Vukovar, Croatia

Barnes, S., Hunt. B. (2000). E-Commerce and V-Business: Business Models for Global Success, Butterworth-Heinemann, ISBN 978-0750645324, Oxford, United Kingdom

Bosilj-Vukšič, V., Stemberger, M., I., Jaklič, J. (2010). Simulation Modelling to Assess the Added Value of Electronic Commerce. Available from http://bib.irb.hr/datoteka/ 89704.MIPRO-Vesna-Bosilj.pdf

Bucki, R. (2008). Mathematical Modelling of Allocation Processes as an Effective Tool to Support Decision Making. Information and Telecommunication Systems, Polish Information Processing Society, The Beskidy Group, Academy of Computer Science and Management, No. 17, Bielsko-Biała, Poland 
Dunn, C., L., Cherrington, J., O., Hollander A., S. (2005). Enterprise Information Systems. A pattern based approach. McGraw-Hill, 397 p., ISBN 0-07-240429-9, New York, USA

ETL-Tools.Info. (2009). Definition and concepts of the ETL processes. 15.11.2009, Available from http://etl-tools.info/en/bi/etl_process.htm

Folorunso, O., Sharma, S., K., Longe, H., O., D., Lasaki, K. (2006). An Agent-based Model for Agriculture E-commerce System. Information Technology Journal 5(2). 2006, ISSN: 1812-5638, pp. 230-234, Available from http://www.docsdrive.com/ pdfs/ansinet/itj/2006/230-234.pdf?sess=jJghHkjfd76K8JKHgh76JG7FHGD redhgJgh7GkjH7Gkjg57KJhT

Garcia, F.J., Paterno, F., Gil, A.B. (2002). An Adaptive e-Commerce System Definition. Springer, Heidelberg, 2002, ISBN 978-3-540-43737-6, Berlin, Germany

Harrison, E. F. (1998). The Managerial Decision-Making Process. Cincinnati: South-Western College Pub. 576 p., ISBN 978-0395908211, Boston, Massachusetts, United States

Hruby, P. (2006). Model Driven Design Using Business Patterns. Heidelberg: Springer Verlag, ISBN 978-3-540-30154-7, Berlin, Germany

Kaminka, G. A. (2004). Robots are Agents, Too! AgentLink News, pp. 16-17, ISBN: 978-81904262-7-5, New York, USA

Laudon, K., Traver, C.G. (2009). E-Commerce 2010 (6th edition), Prentice Hall, ISBN 9780136100577, New Jersey, USA

Laudon, K., Traver, C.G. (2010). E-Commerce 2011 (7th edition), Prentice Hall, ISBN 9780136100577, New Jersey, USA

Lima, P., Bonarini, A., Mataric, M. (2004). Application of Machine Learning, InTech, ISBN 978953-7619-34-3, Vienna, Austria

Li, B., Xu, Y., Choi, J. (1996). Applying Machine Learning Techniques, Proceedings of ASME 2010 4th International Conference on Energy Sustainability, pp. 14-17, ISBN 842-650823-3, Phoenix, Arizona, USA, May 17-22, 2010

Molnár, Z. (2009). Internetové informační zdroje pro strategické plánování. International Conference Internet, Competitivenes and Organisational Security in Knowledge Society. Tomas Bata University in Zlin, ISBN 978-80-7318-828-3, Zlín, Czech Republic

Murillo, L. (2001). Supply chain management and the international dissemination of ecommerce. Industrial Management \& Data Systems. Volume 101, Issue 7, Page 370 377, ISSN 0263-5577, San Francisco, California, USA

Olsen, H. (2003). Supporting customers' decision-making process. [on-line] Retrieved 09.12.2009. URL: <http://www.guuui.com/issues/02_03.php >

Panait, L., Luke, S. (2005). Cooperative Multi-Agent Learning: The State of the Art. Autonomous Agents and Multi-Agent Systems, pp 387-434, [on-line] Retrieved January 3, 2011, <http://cs.gmu.edu/ eclab/papers/panait05cooperative.pdf>

Porter, M. (1980). Competitive Strategy: Techniques for Analyzing Industries and Competitors. Free Press, 398 p., ISBN 978-0684841489, New York, USA

Rajput, W. (2000). E-Commerce Systems Architecture and Applications, Artech House Publishers, ISBN 978-1580530859, London, United Kingdom

Řepa, V. (2006). Podnikové procesy: Procesní rízení a modelování. Grada Publishing, 288 p., ISBN 80-247-1281-4, Prague, Czech Republic

Rogers, A., David, E., Schiff, J. and Jennings, N. R. (2007). The Effects of Proxy Bidding and Minimum Bid Increments within eBay Auctions. ACM Transactions on the Web, 1 (2). article 9-(28 pages).

Simon, A., Shaffer, S. (2001). Data Warehousing and Business Intelligence for E-commerce. Academic press, 320 p., ISBN 1-55860-713-7, London, England 
Sun, R., Naveh, I. (2004). Simulating Organizational Decision-Making Using a Cognitively Realistic Agent Model, Journal of Artificial Societies and Social Simulation, Journal of Artificial Societies and Social Simulation vol. 7, no. 3

<http://jasss.soc.surrey.ac.uk/7/3/5.html>

Schurr, N., Marecki, J., Tambe, M., Scerri, P. (2005). The Future of Disaster Response: Humans Working with Multiagent Teams using DEFACTO, [on-line] Retrieved January 3, 2011, URL: <http://www.aaai.org/Papers/Symposia/Spring/2005/SS05-01/SS05-01-002.pdf>

Siegwart, R. (2001). Indirect Manipulation of a Sphere on a Flat Disk Using Force Information. International Journal of Advanced Robotic Systems. InTech, Vol.6, No.4, (December 2009), pp. 12-16, ISSN 1729-8806

Suchánek, P. (2010a). Business Intelligence as a Support of E-commerce Systems in Connection with Decision Making and Cross-Border Online Shopping. In Journal of Applied Economic Science, Volume V, Issue 1, Spring 2010, ISSN 1843-6110, Dolj, Romania

Suchánek, P., Slaninová, K. \& Bucki, R. (2010b). Business Intelligence as the Support of decision-Making processes in E-commerce Systems Environment. Proceedings of the Workshop Methods and Applications of Artificial Intelligence, The College of Informatics and Management, pp. 5 - 20, ISBN 978-83-62466-02-3, Bielsko-Biala, Poland

Sweiger, M., Madsen, M.R., Langston, J., Lombard, H. (2002). Clickstream Data Warehousing. 1 st edition. Wiley, 456 p., ISBN 978-0471083771, New Jersey, USA

Šperka, R. (2010). Improving the Competitiveness of Enterprises through Multi-agent Systems. Science E Education Foundation: www.science-journals.eu [online]. 2010, Economy \& Business, Volume 4, Part 3. Available from http://www.sciencejournals.eu/economy/2010/ISP-EB-Vol4-Part3.swf, ISSN 1313-2555, Bulgaria

Taniar, D. (2009). Progressive Methods in Data Warehousing and Business Intelligence: Concepts and Competitive Analytics. Information Science Reference. 390 p. ISBN 978-1605662329, Toronto, Canada

Van der Linden, S. (June 2010). Integrating Wind Turbine Generators (WTG's) with Energy Storage, In: Wind Power, 17.06.2010, Available from http://sciyo.com/articles/show/title/wind-power-integrating-wind-turbinegenerators-wtg-s-with-energy-storage

Velmurugan, M., S., Narayanasamy, K. (2008). Aplication of Decision Support System in Ecommerce. Communications of the IBIMA, pp. 156-169, Volume 5, 2008, Available from http://www.ibimapublishing.com/journals/CIBIMA/volume5/v5n19.pdf

Vymětal, D. (2009). Nástin simulace podnikového řídicího systému s použitím agentů, In Informační technologie pro praxi, Ekonomická fakulta VŠB, October 1-2, pp. 158-166, Ostrava, Czech Republic

Vymětal, D., Suchánek, P. (2009). E-business environment in the Global Information Society. V G. w. Korfantego, Podnikání v podminkách Evropské unie. Górnośląska wyższa szkoła Handlova im. Wojciecha Korfantego, ISBN 978-83-60953-24-2, Katowice, Poland

Wolf, P. (2006). Úspěšný podnik na globálním trhu. CS Profi - Public, 240 p., ISBN 80-969546-52, Bratislava, Slovakia

Wooldridge, M. (2002). An Introduction to MultiAgent Systems, John Wiley \& Sons Ltd, 348 p., ISBN 978-0471496915, New Jersey, USA

Young, K., Srivastava, J. (2007). Impact of social influence in e-commerce decision making. In ACM International Conference Proceeding Series, Vol. 258, p. 293 - 302, ISBN 978-159593-700-1, Minneapolis, USA 


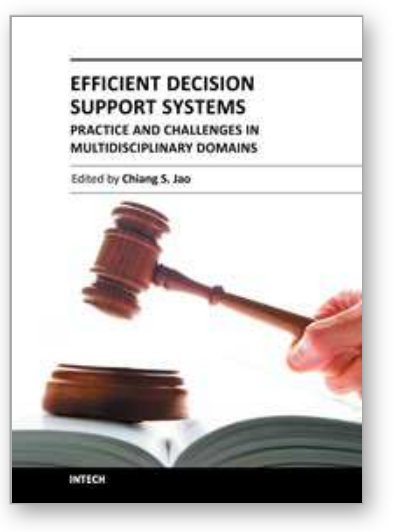

\author{
Efficient Decision Support Systems - Practice and Challenges in \\ Multidisciplinary Domains \\ Edited by Prof. Chiang Jao
}

ISBN 978-953-307-441-2

Hard cover, 478 pages

Publisher InTech

Published online 06, September, 2011

Published in print edition September, 2011

This series is directed to diverse managerial professionals who are leading the transformation of individual domains by using expert information and domain knowledge to drive decision support systems (DSSs). The series offers a broad range of subjects addressed in specific areas such as health care, business management, banking, agriculture, environmental improvement, natural resource and spatial management, aviation administration, and hybrid applications of information technology aimed to interdisciplinary issues. This book series is composed of three volumes: Volume 1 consists of general concepts and methodology of DSSs; Volume 2 consists of applications of DSSs in the biomedical domain; Volume 3 consists of hybrid applications of DSSs in multidisciplinary domains. The book is shaped decision support strategies in the new infrastructure that assists the readers in full use of the creative technology to manipulate input data and to transform information into useful decisions for decision makers.

\title{
How to reference
}

In order to correctly reference this scholarly work, feel free to copy and paste the following:

Petr Suchánek, Roman Sperka, Radim Dolák and Martin Miškus (2011). Intelligence Decision Support Systems in E-commerce, Efficient Decision Support Systems - Practice and Challenges in Multidisciplinary Domains, Prof. Chiang Jao (Ed.), ISBN: 978-953-307-441-2, InTech, Available from:

http://www.intechopen.com/books/efficient-decision-support-systems-practice-and-challenges-inmultidisciplinary-domains/intelligence-decision-support-systems-in-e-commerce

\section{INTECH}

open science | open minds

\section{InTech Europe}

University Campus STeP Ri

Slavka Krautzeka 83/A

51000 Rijeka, Croatia

Phone: +385 (51) 770447

Fax: +385 (51) 686166

www.intechopen.com

\section{InTech China}

Unit 405, Office Block, Hotel Equatorial Shanghai

No.65, Yan An Road (West), Shanghai, 200040, China

中国上海市延安西路65号上海国际贵都大饭店办公楼 405 单元

Phone: +86-21-62489820

Fax: $+86-21-62489821$ 
(C) 2011 The Author(s). Licensee IntechOpen. This chapter is distributed under the terms of the Creative Commons Attribution-NonCommercialShareAlike-3.0 License, which permits use, distribution and reproduction for non-commercial purposes, provided the original is properly cited and derivative works building on this content are distributed under the same license. 